\title{
Optimasi Parameter Pemulusan Algoritma Brown Menggunakan Metode Golden Section Untuk Prediksi Data Tren Positif dan Negatif
}

\author{
Fiqih Akbaria, Arief Setyanto ${ }^{\mathrm{b}}$, Ferry Wahyu Wibowo $^{\mathrm{c}}$ \\ a'Magister Teknik Informatika, Universitas AMIKOM Yogyakarta, siskomaster@gmail.com \\ ${ }^{\mathrm{b}}$ Magister Teknik Informatika, Universitas AMIKOM Yogyakarta, arief_s@amikom.ac.id \\ 'Magister Teknik Informatika, Universitas AMIKOM Yogyakarta, ferry.w@amikom.ac.id
}

\begin{abstract}
Algorithm DES (Double Exponential Smoothing) Brown is a forecasting algorithm used to predict time series data both patterned positive trends and negative trends. However, this algorithm has a weakness in determining the optimum parameter value to minimize forecasting error (MAPE), the parameter value is searched using Golden Section method previously searched manually using repeated experiment. This research uses 60 trend patterned data analyzed for grouping positive and negative trend pattern data which further done forecasting process, evaluation and testing to know what type of data pattern is best. Based on the result, it revealed that optimization parameter yields optimum MAPE value, where parameter value is done forecasting process in positive and negative trend pattern data group yielding average MAPE value equal to 9,73401\% (highly accurate) for patterned data positive trend and 15,78467\% (good forecast) for negative patterned pattern data. DES Brown forecasting algorithm with parameter optimization method resulted in the approximate value of the original data if the data shows the addition or decrease in value around the average value. Conversely, it will result in a high MAPE value (inaccurate) if the data has a spike in data value periods. From the two groups of MAPE scores, a statistical t test showed that positive trend patterned data $(\mu 1)$ yielded better MAPE average value than negative trend patterned data $(\mu 2)$.
\end{abstract}

Keywords: Parameter Optimization, DES Brown, Data Trends, Golden Section, T Test

\begin{abstract}
Abstrak
Algoritma DES (Double Exponential Smoothing) Brown merupakan algoritma peramalan yang digunakan untuk memprediksi data deret berkala baik berpola tren positif maupun tren negatif. Namun algoritma ini mempunyai kelemahan yaitu dalam menentukan nilai parameter optimum untuk meminimasi error peramalan (MAPE), nilai parameter tersebut dicari menggunakan metode Golden Section dimana sebelumnya dicari secara manual menggunakan percobaan berulang kali. Penelitian ini menggunakan 60 data berpola tren yang dianalisis untuk pengelompokan pola data tren positif dan negatif dimana selanjutnya dilakukan proses peramalan, evaluasi dan pengujian untuk mengetahui jenis pola data tren apa yang terbaik. Dari hasil perhitungan dan pengujian diketahui bahwa parameter optimasi menghasilkan nilai M APE y ang optimum, dimana selanjutny a nilai parameter tersebut dilakukan proses peramalan pada kelompok pola data tren positif dan negatif y ang menghasilkan rata-rata nilai MAPE sebesar 9,73401\% (highly accurate) untuk data berpola tren positif dan 15,78467\% (good forecast) untuk data berpola tren negatif. Algoritma peramalan DES Brown dengan metode optimasi parameter menghasilkan nilai pendekatan terhadap data asli jika data tersebut menunjukkan penambahan atau penurunan nilai disekitar nilai rata-rata. Sebaliknya, akan menghasilkan nilai MAPE yang tinggi (tidak akurat) jika data tersebut memiliki lonjakan periode nilai data. Dari kedua kelompok nilai MAPE tersebut dilakukan uji t statistik yang menyatakan bahwa data berpola tren positif $(\mu 1)$ menghasilkan nilai rata-rata MAPE lebih baik dibandingkan data berpola tren negatif $(\mu 2)$.
\end{abstract}

Kata Kunci: Optimasi Parameter, DES Brown, Data Tren, Golden Section, T Test

(C) 2018 Jurnal RESTI

\section{Pendahuluan}

Terdapat berbagai macam pola data runtun waktu yang dapat digunakan untuk peramalan, salah satunya adalah Namun masalah yang muncul pada algoritma ini adalah pola data tren. Algoritma DES Brown merupakan salah dalam menentukan nilai parameter optimum untuk satu dari algoritma DES (Double Exponential memberikan ukuran kesalahan peramalan terkecil. Smoothing) yang digunakan dalam peramalan untuk Biasanya untuk mendapatkan parameter optimum dicari menggunakan metode coba dan salah (trial and error)

\begin{tabular}{l|l|l} 
Diterima Redaksi : 27-02-2018 & Selesai Revisi : 22-03-2018 & Diterbitkan Online : 16-04-2018
\end{tabular} 
membutuhkan waktu yang cukup banyak [2] dan peramalan pada masing-masing kelompok untuk penelitian yang ada hanya menerapkan peramalan pada dievaluasi dan diuji dalam menentukan pola data tren salah satu pola data tersebut. Beda halnya pada mana yang terbaik berdasarkan nilai uji $\mathrm{T}$ statistik dari penelitian ini, parameter algoritma DES Brown tersebut kedua kelompok nilai MAPE yang dihasilkan.

dioptimasi untuk dicari nilai optimumnya menggunakan

algoritma non linear programming [3] yaitu metode 2.2 Peramalan DES Brown

golden section yang diimplementasikan pada kedua pola data tren tersebut.

Peramalan adalah suatu prediksi dari kejadian atau beberapa kejadian di masa depan [5] dalam pengertian

Data yang digunakan adalah 60 data berpola tren yang lain yaitu suatu prediksi untuk mencapai kejadian yang diperoleh dari Badan Pusat Statistik (BPS) dan akan datang secara sistematis menggunakan data di Kementrian ESDM dimana data tersebut dianalisis masa lalu [6]. Ada 2 kategori model peramalan yang menggunakan least square method untuk diperlukan dalam membuat suatu keputusan yaitu model pengelompokan pola data tren positif dan pola data tren kualitatif (opinion and judgmental methods) dan model negatif [4]. Hasil peramalan dari kedua kelompok pola kuantitatif (time series)[7]. Algoritma peramalan DES tersebut akan dievaluasi dan diuji menggunakan uji t Brown merupakan peramalan data yang berpola tren statistik untuk membandingkan apakah rata-rata nilai dengan menggunakan persamaan sebagai berikut: [8]

MAPE (mean absolute percentage error) memiliki perbedaan atau tidak dalam menentukan pola data tren terbaik.

\section{Tinjauan Pustaka}

Adapun tinjauan pustaka yang digunakan pada penelitian ini adalah sebagai berikut:

$$
\begin{aligned}
& S_{t}^{\prime}=\alpha X_{t}+(1-\alpha) S_{t-1}^{\prime} \\
& S_{t}^{\prime \prime}=\alpha S_{t}^{\prime \prime}+(1-\alpha) S_{t-1}^{\prime \prime} \\
& a_{t}=2 S_{t}^{\prime}-S_{t}^{\prime \prime} \\
& b_{t}=\frac{\alpha}{1-\alpha}\left(S_{t}^{\prime}-S_{t}^{\prime \prime}\right) \\
& F_{t+m}=a_{t}+b_{t} m
\end{aligned}
$$

Dengan $X_{t}=$ data aktual pada periode $t, \alpha=$ parameter pemulusan, $S_{t}^{\prime}=$ pemulusan eks ponensialtunggal pada periode $t, S_{t}^{\prime \prime}=$ pemulusan eksponensial ganda pada periode $t, a_{t}$ dan $b_{t}=$ pemulusan trend pada periode $t$, $F_{t+m}=$ peramalan untuk periode ke depan dari $t, t=$ periode ke - dan $m=$ periode jumlah ramalan ke depan.

\subsection{Metode Golden Section}

Metode Golden Section adalah metode yang digunakan untuk menyelesaikan masalah non linear programming satu variabel yang berbentuk maksimasi atau minimasi : $f(\mathrm{x})$ dengan kendala nilai $\mathrm{a} \leq \alpha \leq \mathrm{d}$ [2]. Metode golden section ini pada dasarnya mengurangi daerah batas $(\alpha)$ yang mungkin menghasilkan nilai fungsi objektif optimum secara iteratif. Misalkan pada suatu tahap iterasi nilai fungsi optimum mungkin terletak pada interval $\alpha[a, d]$. Selanjutnya menentukan dua nilai $\alpha$ yang simetris dalam interval tersebut yaitu b dan c, dan interval kemungkinan fungsi bernilai optimum dikurangi dari $[a, d]$ menjadi $[a, c]$ atau $[b, d]$ tergantung dari nilai fungsi di $\alpha=\mathrm{b}$ dan di $\alpha=\mathrm{c}$. Untuk fungsi unimodal yaitu fungsi dengan satu nilai minimum, apabila nilai $f(\mathrm{~b})<f(\mathrm{c})$ maka interval dapat dikurangi menjadi [a,c]. Sedangkan apabila nilai $f(b)>f(c)$ interval dapat dikurangi menjadi $[\mathrm{b}, \mathrm{d}]$. Langkah iterasi diulangi sampai interval $\alpha$ sangat kecil tergantung dari nilai yang dikehendaki, dan dapat diambil bahwa $\alpha$ minimum terletak pada interval akhir tersebut.[9]

Untuk mendapatkan nilai b dan c dapat menggunakan persamaan berikut : [10]

$\mathrm{b}=\mathrm{ra}+(1-\mathrm{r}) \mathrm{d}$

$c=a+d-b$

60 data berpola tren. Setiap data dilakukan analis is untuk pengelompokan pola data yang kemudian dilakukan

dengan 
$r=(-1+\sqrt{5}) / 2$

Jika $f(\mathrm{~b})<f(\mathrm{c})$ maka menggunakan persamaan : (9) $\mathrm{d}=\mathrm{c}$

$\mathrm{c}=\mathrm{b}$

$\mathrm{b}=r \mathrm{a}+(1-\mathrm{r}) \mathrm{d}$

Jika $f(\mathrm{~b})>f(\mathrm{c})$ maka menggunakan persamaan : (10)

$\mathrm{a}=\mathrm{b}$

$\mathrm{b}=\mathrm{c}$

$c=a+d-b$

\subsection{Ukuran Akurasi Peramalan}

Akurasi dari suatu peramalan adalah sangat penting. Peramalan yang dihasilkan tidak pernah $100 \%$ tepat, hasilnya selalu lebih tinggi atau lebih rendah dari nilai sebenarnya. Dalam banyak situasi peramalan, ketepatan dipandang sebagai kriteria penolakan untuk memilih suatu metode peramalan [8]. Menurut Makridakis et al (1988) salah satu indikator yang dapat digunakan untuk menghitung kesalahan dalam peramalan adalah nilai MAPE (Mean Absolute Percentage Error) atau dapat juga disebut nilairata-rata kesalahan persentase absolut, yang dapat dihitung menggunakan persamaan berikut :

$$
\begin{array}{ll}
E_{t} & =X_{t}-F_{t} \\
P E_{t} & =\left(\frac{E_{t}}{X_{t}}\right) 100 \\
A P E_{t} & =a b s\left(P E_{t}\right) \\
j \operatorname{lhAPE} & =\operatorname{SUM}\left(A P E_{t}\right) \\
M A P E & =j \operatorname{lh} A P E / j \operatorname{lh}(t)
\end{array}
$$

Dengan $E_{t}=$ kesalahan prediksiuntuk pada periode t, $X_{t}$ Kemudian selanjutnya rumus yang digunakan untuk uji $=$ nilai data aktual periode $t, F_{t}=$ nilai ramalan periode $\mathrm{t}$ tidakberpasangan (unpaired/independent) adalah:[15] $t, P E_{t}=$ persentase kesalahan, $A P E_{t}=$ persentase kesalahan absolut, $j \operatorname{lh} A P E=$ jumlah persentase kesalahan absolut, $j l h(t)=$ jumlah periode ramalan dan $M A P E=$ persentase nilai rata-rata kesalahan absolut.

Skala untuk menilai akurasi peramalan yang berdasarkan nilai MAPE dikembangkan oleh Lewis (1982) yang tercantum pada Tabel 1 [11]

Tabel 1. Skala dari Penilaian Akurasi Peramalan

\begin{tabular}{cc}
\hline MAPE & Penilaian Dari Akurasi Peramalan \\
\hline Kurang dari 10\% & Berakurasi tinggi (Highly Accurate) \\
$11 \%$ sampai 20\% & Peramalan yang baik (GoodForecast) \\
$21 \%$ sampai 50\% & Peramalan dengan alasan \\
& (Reasonable Forecast) \\
Lebih dari 50\% & $\begin{array}{c}\text { Peramalan tidak akurat } \\
\text { (Inaccurate Forecast) }\end{array}$ \\
\hline
\end{tabular}

\subsection{Uji T Statistik}

Uji t adalah salah satu uji statistik yang digunakan untuk mengetahui ada tidaknya perbedaan yang signifikan (menyakinkan) dari dua buah mean sampel dari dua variabel yang dikomparatifkan [12]. Uji t terbagi menjadi dua yaitu berpasangan (paired) dan tidak berpasangan (unpaired/independent) dimana terdapat hipotesis one tailed (satu sisi) dan two tailed (dua sisi) dalam perumusan hipotesisnya. [13]. Adapun perumusan hipotesisnya sebagai berikut, lihat Tabel 2.

Tabel 2. One tailed dan two tailed

\begin{tabular}{ccc}
\hline $\begin{array}{c}\text { One tailed sisi } \\
\text { kiri }\end{array}$ & $\begin{array}{c}\text { One tailed sisi } \\
\text { kanan }\end{array}$ & $\begin{array}{c}\text { Two Tailed (dua } \\
\text { sisi) }\end{array}$ \\
\hline$H_{0}: \mu 1 \geq \mu 2$, & $H_{0}: \mu 1 \leq \mu 2$, & $H_{0}: \mu 1=\mu 2$, \\
$H_{1}: \mu 1<\mu 2$ & $H_{1}: \mu 1>\mu 2$ & $H_{1}: \mu 1 \neq \mu 2$ \\
Tolak $H_{0}$ bila & Tolak $H_{0}$ bila & Tolak $H_{0}$ bila \\
$t_{\text {stat }}<t_{\text {crit }}$ & $t_{\text {stat }}>t_{\text {crit }}$ & $t_{\text {stat }}>t_{\text {crit }}$ \\
\hline
\end{tabular}

Rumus yang digunakan untuk ujit berpasangan (paired) adalah : [14]

$t_{\text {stat }}=\frac{\left(\frac{\Sigma D}{n}\right)}{\left(\frac{S D}{\sqrt{n-1}}\right)}$

dengan rumus mencari nilai SD (standar deviasi) yaitu:

$S D=\sqrt{\frac{\Sigma D^{2}}{n}-\left(\frac{\Sigma D}{n}\right)^{2}}$

$d f=n-1$

Dengan $t_{\text {stat }}=\mathrm{T}$ statistik, $n=$ banyaknya data, $D=$ deviasi, $S D=$ standar deviasi, $d f=$ degree of freedom. Untuk mendapatkan nilat $t_{c r i t}$ adalah pembacaan nilai $\mathrm{t}$ tabel distribusi dari nilai $d f$ (derajat kebebasan) dan nilai signifikansi alpha $(\alpha)$.

Jika equal variance :

$t=\frac{(\bar{X}-\bar{Y})}{\sqrt{\left(\frac{S_{x}^{2}}{n_{1}}+\frac{S_{y}^{2}}{n_{2}}\right)}}$

$S_{p}^{2}=\frac{\left(n_{1}-1\right) S_{x}^{2}+\left(n_{2}-1\right) S_{y}^{2}}{n_{1}+n_{2}-2}$

$d f=n_{1}+n_{2}-2$

Jika unequal variance :

$$
\begin{gathered}
t=\frac{(\bar{X}-\bar{Y})}{\sqrt{\left(\frac{S_{x}^{2}}{n_{1}}+\frac{S_{y}^{2}}{n_{2}}\right)}} \\
d f=\frac{\left(\frac{S_{x}^{2}}{n_{1}}+\frac{S_{y}^{2}}{n_{2}}\right)^{2}}{\frac{\left(\frac{S_{x}^{2}}{n_{1}}\right)^{2}}{n_{1}-1}+\frac{\left(\frac{S_{y}^{2}}{n_{2}}\right)^{2}}{n_{2}-1}}
\end{gathered}
$$


Dengan rumus mencari nilai varian sebagai berikut :

$$
\begin{aligned}
& S_{x}^{2}=\frac{\sum(X-\bar{X})^{2}}{n-1} \\
& S_{y}^{2}=\frac{\sum(Y-\bar{Y})^{2}}{n-1}
\end{aligned}
$$

Untuk mengetahui apakah kelompok data tersebut equal atau unequal dapat diuji menggunakan rumus $F_{\text {stat }}$ :

$$
F_{\text {stat }}=\frac{H I G H S^{2}}{\text { LOW } S^{2}}=\frac{\text { Varian terbesar }}{\text { Varian terkecil }}
$$

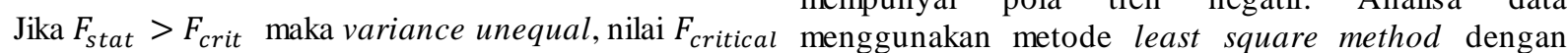
didapat daritabelF distribution yang sesuaidengan nilai perhitungan yang hasil akhirnya memenuhi persamaan signifikansi $(\alpha)$ yang digunakan. Dimana $\bar{X}=$ rata-rata $Y=a+b X$ untuk pola tren positif dan $Y=a-b X$ kelompok $1, \bar{Y}=$ rata-rata kelompok $2, S_{x}^{2}=$ varian untuk pola tren negatif dengan $a=\frac{\sum Y}{n}$ dan $b=\frac{\sum X Y}{\sum X^{2}}$
kelompok $1, S_{y}^{2}=$ Varian kelompok $2, S_{p}^{2}=$ pooled variance, $n=$ banyaknya data, $d f=$ degree offreedom.

\section{Metodologi Penelitian}

Langkah yang dilakukan dalam penelitian, disajikan Pada tahap ini algoritma peramalan DES Brown pada Gambar 1.

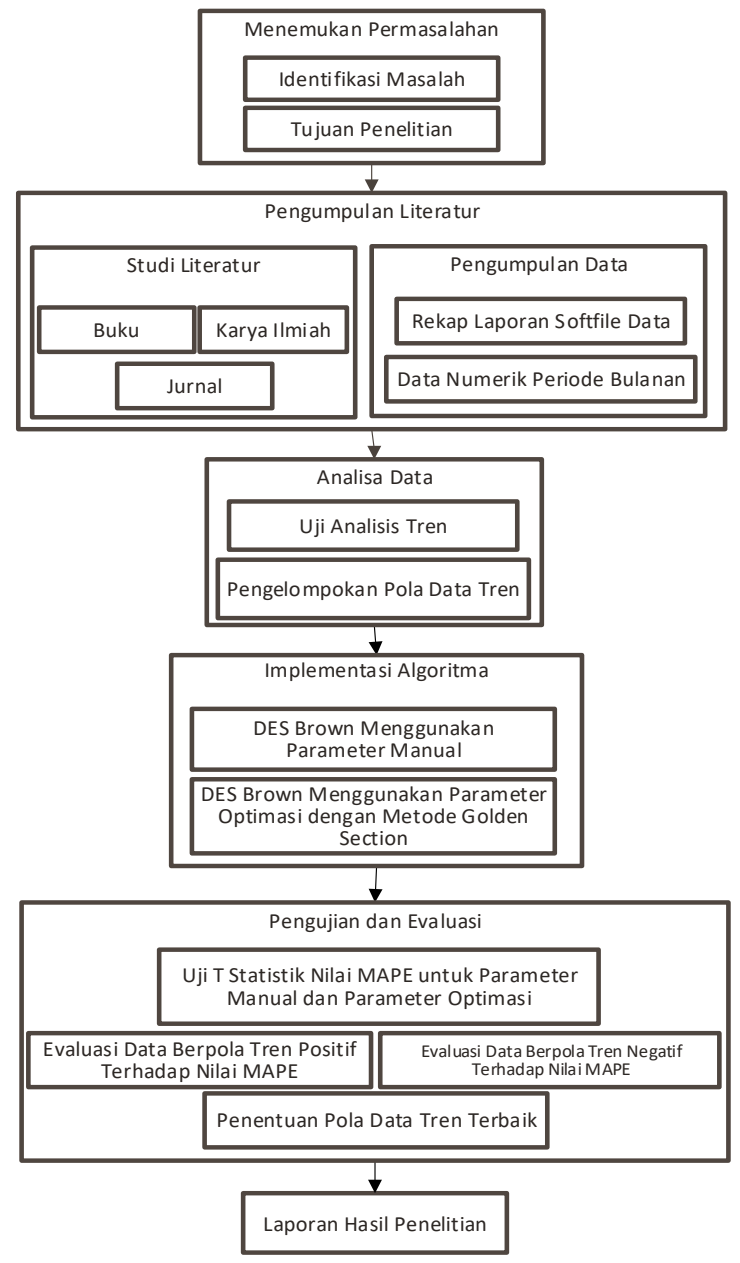

Gambar 1. Metodologi Penelitian

\subsection{Pengumpulan Data}

Penelitian ini menggunakan 60 data berpola tren yang liperoleh dari situs resmi Badan Pusat Statistik (BPS) indonesia dan Kementrian ESDM Indonesia [16][17]. Data ini dalam bentuk data numerik yaitu deret berkala periode bulanan selama beberapa tahun mencakup pola data tren yang kemudian pada tahap selanjutnya akan dianalisa.

\subsection{Analis is Data}

Analisis data dilakukan untuk pengelompokan hasil pengumpulan data yang berpola tren, data mana yang mempunyai pola tren positif dan data mana saja yang mempunyai pola tren negatif. Analisa data [4].

\subsection{Implementasi Algoritma}

diimplementasikan menggunakan parameter manual yaitu melakukan percobaan nilai parameter dari 0 hingga 1 dan menggunakan parameter optimasi dengan metode golden section. Hal ini bertujuan untuk mengukur seberapa baik optimasi yang dilakukan, apakah hasil akurasi peramalan berbeda jauh secara signifikan atau tidak. Implementasi ini dilakukan terhadap kedua kelompok pola data.

\subsection{Pengujian dan Evaluasi}

Pada tahap ini hasil dari penerapan algoritma DES Brown menggunakan parameter manual dan parameter optimasi akan diuji menggunakan uji $\mathrm{T}$ statistik, nilai MAPE yang dihasilkan dari kedua kelompok parameter tersebut yaitu parameter manual (sebelum dioptimasi) dan sesudah dioptimasi diuji T statistik apakah nilainya berbeda secara signifikan atau tidak ada perbedaan dari keduanya. Setelah diketahui parameter yang optimum, kemudian parameter tersebut diaplikasikan pada kelompok data berpola data tren positif dan berpola tren negatif, yang dimana hasil tersebut diuji lagi menggunakan uji t statistik dalam penentuan pola data tren terbaik.

\section{Hasil dan Pembahasan}

Hasil penelitian yang dilakukan, disajikan berikut ini:

\subsection{Hasil Pengumpulan Data}

Data yang didapat yaitu 60 data berpola tren, yaitu data jumlah kunjungan wisatawan mancanegara menurut pelabuhan masuk sebanyak 10 data dengan 113 periode, jumlah penumpang dan jumlah barang melalui transportasi kereta sebanyak 7 data dengan 137 periode, jumlah penumpang pesawat di bandara utama 
keberangkatan pada internasional dan domestik Gambar 2 dan Gambar 3 adalah plot grafik hasil nilai sebanyak 9 data dengan 137 periode, jumlah barang MAPE yang didapatkan menggunakan parameter yang dimuat dan dibongkar di bandara utama manual dari beberapa data tren yang berpola tren positif penerbangan internasional dan domestik sebanyak 13 dan berpola tren negatif.

data dengan 117 periode, jumlah indeks unit value ekspor bulanan sebanyak 20 data dengan 43 periode dan data rata-rata harga minyak mentah Indonesia sebanyak 1 data dengan 65 periode.

\subsection{Hasil Analisa Data}

Dari analisis 60 data berpola tren menggunakan perhitungan metode least square method didapatkan persamaan tren bepola positif sebanyak 30 data dan berpola negatif sebanyak 30 data.

\subsection{Hasil Implementasi Algoritma}

Implementasi algoritma peramalan Brown dilakukan pada nilai parameter manual dan nilai parameter dengan optimasi menggunakan metode golden section yang bertujuan untuk melihat apakah hasil akurasi peramalan berbeda jauh secara signifikan atau tidak. Peramalan ini menggunakan 30 data berpola tren positif dan 30 data berpola tren negatif.

\subsubsection{Peramalan Menggunakan Parameter Manual}

Yang dimaksud dengan parameter manual disini adalah mengeset nilai parameter dengan mencoba peramalan menggunakan nilai parameter dari 0,1 sampai 0,9 untuk mendapatkan nilai MAPE optimum. Berikut langkahnya:

1. Mengeset nilai parameter alpha $(\alpha=0-1)$.

2. Menginisialisasi nilai pemulusan pertama $\left(S^{\prime}\right)$ dan pemulusan kedua $\left(S^{\prime \prime}\right)$.

3. Menghitung nilai $S^{\prime}, S^{\prime \prime}, a$, dan $b$ pada satu periode berikutnya menggunakan persamaan (1) sampai dengan persamaan (4).

4. Menghitung nilai ramalan satu periode berikutnya $(m=1)$ menggunakan persamaan (5).

5. Mengulang langkah 3 sampai 4 untuk seluruh data periode.

6. Menghitung nilai MAPE dari data periode susunan pengujian dengan rasio 40:60 menggunakan persamaan (11) hingga (15). [8]

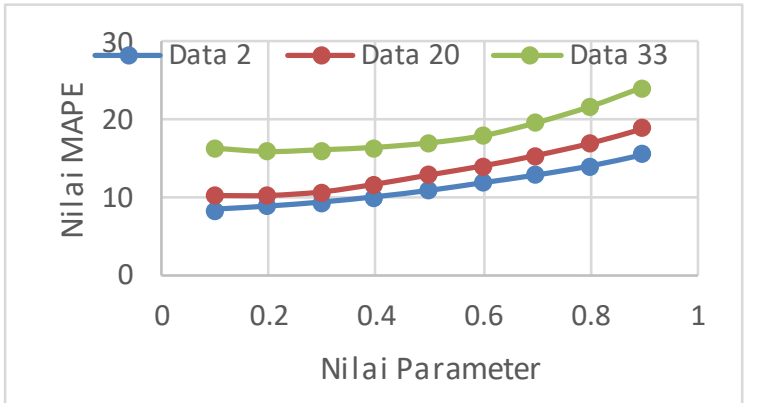

Gambar 2. Grafik Plot Nilai MAPE terhadap nilai parameter unt uk beberapa data yang berpola tren positif.

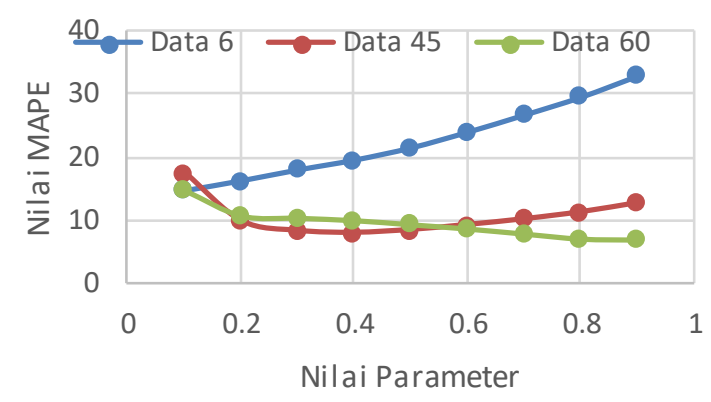

Gambar 3. Grafik Plot Nilai MAPE terhadap nilai parameter untuk beberapa data yang berpola tren negatif.

Perhitungan nilai MAPE menggunakan parameter manual untuk data berpola tren positif diketahui bahwa sebagian besar nilai parameter yang kecil menghasilkan nilai galat peramalan terkecil, selain itu dengan menggunakan parameter manual yang dihitung dari $\alpha=$ 0,1 sampai dengan $\alpha=0,9$ memerlukan banyak waktu dan percobaan berulang kali dalam menemukan nilai parameter yang optimum untuk mencari nilai MAPE minimum.

Hasil nilai MAPE yang diperoleh dari data berpola tren negatif diketahui bahwa tidak semua parameter dengan nilai kecil akan menghasilkan nilai MAPE yang kecil pula.

\subsubsection{Peramalan Menggunakan Parameter Optimasi}

Langkah perhitungannya sebagai berikut :

1. Mengeset nilai toleransi $\varepsilon=0,00001, a=0$ dan $d=1$.

2. Menghitung nilai $b$ dan $c$ menggunakan persamaan (6) dan (7).

3. Menghitung nilai fungsi $f(b)$ dan $f(c)$, nilai $b$ dan $c$ ini adalah nilai parameter $\alpha$ yang dicari menggunakan langkah perhitungan MAPE.

4. Menghitung nilai $d-a$ sampai memenuhi nilai toleransi yang ditentukan, jika iterasi maksimum, iterasi selesai, maka nilai $\alpha=\mathrm{b}=\mathrm{c}$ (konvergen).

5. Membandingkan nilai $f(b)$ dan $f(c)$, menggunakan persamaan (9) dan (10).

Hasil peritungan optimasi dengan nilai parameter yang optimum dapat dilihat pada Tabel 3 untuk optimasi data 1 (tren positif).

Berdasarkan Tabel 3 nilai hasil optimasi parameter diatas pada data 1 yang telah dilakukan, nilai parameter yg optimum menggunakan metode golden section terletak pada nilai $b$ dan $c$ yang konvergen dengan nilai $d-a=$ nilai toleransi $(\varepsilon=0,00001)$ yang telah 
ditetapkan. Sehingga hasil akhir terletak pada iterasi ke 4.4.1. Uji T Statistik Nilai MAPE Untuk Parameter 26 dengan nilai parameter optimum adalah $\alpha=0,14462$ Manual dan Parameter Optimasi.

dan nilai MAPE optimum sebesar 7,38916\%.

Tabel 3. Proses Perhitungan Mencari Parameter Optimum

\begin{tabular}{cccccc}
\hline Iterasi & $b$ & $c$ & $d-a$ & $f(b)$ & $f(c)$ \\
\hline 1 & 0.38197 & 0.61803 & 1.00000 & 8.11612 & 9.17275 \\
2 & 0.23607 & 0.38197 & 0.61803 & 7.44240 & 8.11612 \\
$\vdots$ & $\vdots$ & $\vdots$ & $\vdots$ & $\vdots$ & $\vdots$ \\
24 & 0.14462 & 0.14462 & 0.00002 & 7.38916 & 7.38916 \\
25 & 0.14462 & 0.14463 & 0.00001 & 7.38916 & 7.38916 \\
26 & 0.14462 & 0.14462 & 0.00001 & 7.38916 & 7.38916 \\
27 & 0.14462 & 0.14462 & 0.00000 & 7.38916 & 7.38916 \\
28 & 0.14462 & 0.14462 & 0.00000 & 7.38916 & 7.38916 \\
\hline
\end{tabular}

Berikut hasil optimasi yang dilakukan pada data berpola hipotesis alternatif $\left(H_{1}: \mu 1>\mu 2\right)$ diterima (accept) tren positif menggunakan parameter optimasi, disajikan yang menyatakan kelompok parameter manual pada Tabel 4.

Tabel 4. Hasil Optimasi Parameter Pada Data Berpola Tren Positif

\begin{tabular}{cclccl}
\hline Data & $\alpha$ & MAPE & Data & $\alpha$ & MAPE \\
\hline 1 & 0,144 & 7,389 & 21 & 0,127 & 7,828 \\
2 & 0,092 & 8,422 & 22 & 0,113 & 6,572 \\
3 & 0,101 & 15,435 & 23 & 0,089 & 6,389 \\
4 & 0,030 & 10,459 & 24 & 0,158 & 7,890 \\
5 & 0,163 & 10,272 & 25 & 0,134 & 7,227 \\
11 & 0,126 & 12,663 & 26 & 0,108 & 7,301 \\
12 & 0,354 & 6,161 & 27 & 0,110 & 14,226 \\
13 & 0,151 & 5,995 & 28 & 0,102 & 7,742 \\
14 & 0,327 & 4,400 & 29 & 0,134 & 9,408 \\
15 & 0,185 & 7,398 & 30 & 0,332 & 21,494 \\
16 & 0,189 & 4,112 & 31 & 0,058 & 11,270 \\
17 & 0,197 & 9,207 & 32 & 0,341 & 20,648 \\
18 & 0,105 & 7,108 & 33 & 0,202 & 15,876 \\
19 & 0,032 & 7,708 & 34 & 0,215 & 12,572 \\
20 & 0,060 & 10,264 & 36 & 0,162 & 8,568 \\
\hline
\end{tabular}

Untuk hasil optimasi yang dilakukan pada data berpola 4.4.2. Evaluasi Data Berpola Tren Positif dan Negatif tren negatif menggunakan parameter optimasi, disajikan Terhadap Nilai MAPE pada Tabel 5.

Tabel 5. Hasil Optimasi Parameter Pada Data Berpola Tren Negatif

\begin{tabular}{cclccl}
\hline Data & $\alpha$ & MAPE & Data & $\alpha$ & MAPE \\
\hline 6 & 0,067 & 14,606 & 46 & 0,192 & 12,002 \\
7 & 0,063 & 11,194 & 47 & 0,396 & 23,290 \\
8 & 0,322 & 32,497 & 48 & 0,270 & 4,231 \\
9 & 0,217 & 25,936 & 49 & 0,164 & 2,124 \\
10 & 0,441 & 13,471 & 50 & 0,180 & 6,061 \\
35 & 0,225 & 15,810 & 51 & 0,108 & 7,139 \\
37 & 0,128 & 13,288 & 52 & 0,082 & 25,218 \\
38 & 0,108 & 9,899 & 53 & 0,127 & 17,399 \\
39 & 0,220 & 18,133 & 54 & 0,093 & 10,639 \\
40 & 0,291 & 26,493 & 55 & 0,184 & 28,803 \\
41 & 0,129 & 13,511 & 56 & 0,126 & 5,879 \\
42 & 0,334 & 39,492 & 57 & 0,070 & 9,921 \\
43 & 0,398 & 8,369 & 58 & 0,137 & 6,495 \\
44 & 0,114 & 21,049 & 59 & 0,048 & 35,448 \\
45 & 0,411 & 8,018 & 60 & 0,890 & 7,110 \\
\hline
\end{tabular}

4.4 Pengujian dan Evaluasi

Hasil pengujian dan evaluasi yang dilakukan yaitu sebagai berikut:
Perhitungan uji t statistik dilakukan menggunakan rumus untuk uji t berpasangan (paired) (16) dan rumus standar deviasi (17). Untuk perhitungan kelompok data berpola tren positif didapat nilai $t_{\text {stat }}$ sebesar 3,37547. Dengan nilai degree of freedom yaitu $n-1=29$, dan nilai tingkat signifikansi alpha $(\alpha)$ sebesar $=0.05$, sehingga didapatkan nilai $t_{\text {crit }}$ one tailed sebesar 1.69913 dari t tabel statistik, sehingga:

$t_{\text {stat }}>t_{\text {crit }}=3.37547>1.69913$

menghasilkan rata-rata nilai MAPE lebih besar dari parameter optimasi.

Sedangkan untuk perhitungan kelompok data berpola tren negatif didapat nilai $t_{\text {stat }}$ sebesar 3,37696. Dengan nilai degree of freedom $=n-1=29$, dan nilai tingkat signifikansi alpha $(\alpha)$ sebesar $=0.05$, sehingga didapatkan nilai $t_{\text {crit }}$ one tailed sebesar 1.69913 dari t tabel statistik, sehingga :

$t_{\text {stat }}>t_{\text {crit }}=3.37696>1.69913$

Maka hipotesis awal $\left(H_{0}: \mu 1 \leq \mu 2\right)$ ditolak (reject) dan hipotesis alternatif $\left(H_{1}: \mu 1>\mu 2\right)$ diterima (accept) yang menyatakan kelompok parameter manual menghasilkan rata-rata nilai MAPE lebih besar dari parameter optimasi. Dari kedua perhitungan uji t statistik maka dapat dikatakan bahwa parameter optimasi lebih baik dalam menghasilkan nilai MAPE yang optimum.
Didapat hasil peramalan menggunakan parameter optimasi pada salah satu data berpola tren positif dan tren negatif yaitu pada Gambar 4 dan Gambar 5. (plot grafik)

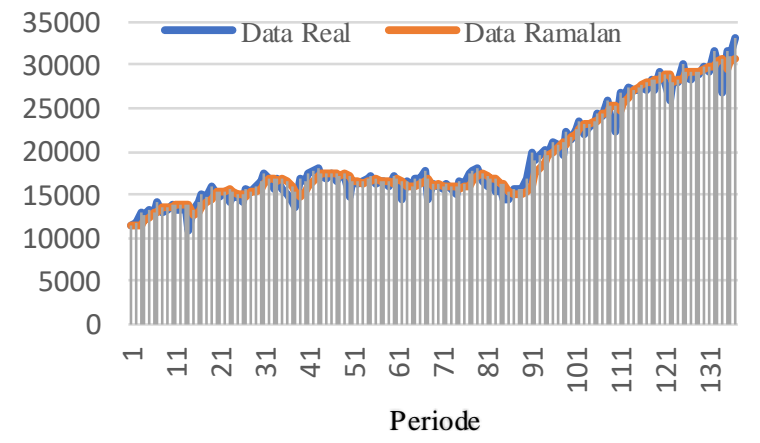

Gambar 4. Plot Perbandingan Data Aktual dengan Data Ramalan pada Data 16

Jurnal RESTI (Rekayasa Sistem dan Teknologi Informasi) Vol . 2 No. 1 (2018) 307- 314 


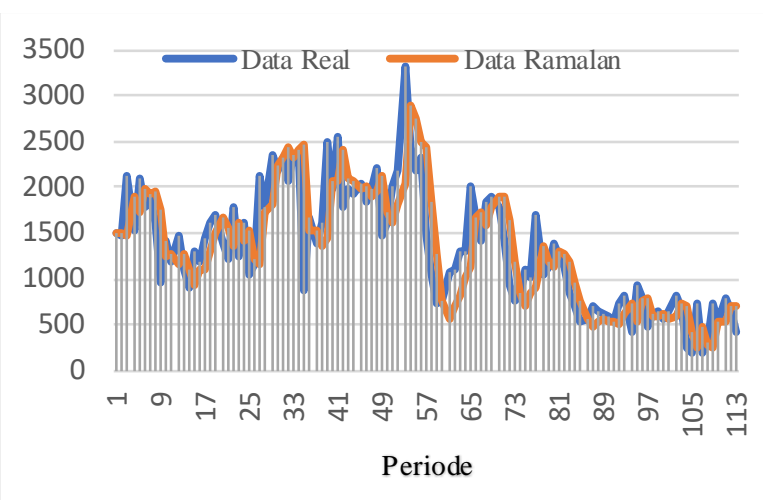

Gambar 5. Plot Perbandingan Data Aktual dengan Data Ramalan pada Data 8

Dari plot grafik hasil peramalan tersebut didapat bahwa Peramalan menggunakan algoritma DES Brown dengan metode optimasi parameter menghasilkan nilai pendekatan terhadap data asli jika data tersebut menunjukkan penambahan atau penurunan nilai di sekitar nilai rata-rata, baik itu data berpola tren positif 3 . maupun tren negatif. Sebaliknya, akan menghasilkan nilai MAPE yang tinggi (tidak akurat) jika pada periode nilai data tersebut memiliki lonjakan nilai data.

\subsubsection{Penentuan Pola Data Tren Terbaik}

Nilai MAPE optimum dari kedua kelompok data tren positif dan negatif yang telah didapat, diuji kembali menggunakan uji t statistik. Uji t yang digunakan adalah $\mathrm{t}$ test independen/unpaired (tidak berpasangan) dikarenakan data yang diuji menggunakan dari 2 kelompok (populasi) yang berbeda. Sebelum uji $\mathrm{t}$ dilakukan, perlu mengetahui kedua kelompok tersebut memiliki varian equal atau tidak equal menggunakan rumus (24) hingga (26). Hasil perhitungan didapat bahwa pada kedua kelompok tersebut memiliki variance unequal dengan $F_{\text {stat }}>F_{\text {crit }}$.

Selanjutnya menggunakan rumus $\mathrm{t}$ test independent unequal dari persamaan (22) dan (23), didapatkan hasil $t_{\text {stat }}<t_{\text {crit }}=-3.09071<1.68488$ dengan hipotesis awal $\left(H_{0}: \mu 1 \geq \mu 2\right)$ ditolak (reject) dan hipotesis alternatif $\left(H_{1}: \mu 1<\mu 2\right)$ diterima (accept) yang menyatakan bahwa terdapat perbedaan dari kedua nilai kelompok tersebut dengan nilai rata-rata MAPE pola data tren positif $(\mu 1)$ lebih kecil dibanding nilai rata-rata MAPE pola data tren negatif $(\mu 2)$. Kelompok data berpola tren positif memperoleh rata-rata nilai MAPE optimum sebes ar $9,73401 \%$ (highly accurate) dan untuk kelompok data berpola tren negatif diperoleh rata-rata nilai MAPE sebesar 15,78467\% (good forecast).

\section{Kesimpulan}

Berdasarkan penelitian yang telah dilakukan maka didapat kesimpulan dan saran sebagai berikut:

\subsection{Kesimpulan}

1. Penggunaan parameter manual memberikan tingkat nilai rata-rata kesalahan peramalan yang tidak tentu bergantung kepada pemilihan interval parameternya dan memerlukan perhitungan yang berulang kali, sementara nilai parameter yang menggunakan metode optimasi golden section menghasilkan nilai error peramalan yang lebih kecil, dengan uji $t$ statistik yang menyatakan bahwa nilai rata-rata error peramalan menggunakan parameter manual $(\mu 1)$ lebih besar dibanding nilai rata-rata error peramalan menggunakan parameter optimasi $(\mu 2)$.

2. Peramalan algoritma DES Brown menggunakan metode optimasi parameter menghasilkan nilai pendekatan terhadap data asli dan pencarian nilai parameter optimum tidak dilakukan berulang kali sehingga menjadi lebih efektif. Nilai rata-rata error peramalan akan menghasilkan nilai yang tinggi jika pada data tersebut memiliki lonjakan periode nilai data yang besar (data 8).

Data yang berpola tren positif menghasilkan nilai rata-rata MAPE lebih baik dibandingkan data yang berpola tren negatif, dengan uji t statistik yang menyatakan bahwa $\mathrm{H}_{-} 1: \mu 1<\mu 2$ yaitu nilai rata-rata MAPE pola data tren positif $(\mu 1)$ lebih kecil dibanding nilai rata-rata MAPE pola data tren negatif $(\mu 2)$. Dimana nilai rata-rata MAPE yang diperoleh sebesar $9,73401 \%$ (highly accurate) untuk data berpola tren positif dan 15,78467\% (good forecast) untuk data berpola tren negatif.

\subsection{Saran}

1. Menggunakan algoritma peramalan dua parameter untuk data berpola tren positif dan tren negatif dengan modifikasi metode optimasi parameter.

2. Menggunakan metode optimasi parameter satu variabel yang lain seperti metode pencarian seragam (uniform search), kuadratis (quadratic search) dan turunan pertama (newton raphson) untuk proses evaluasi parameter dari faktor kecepatan dan ketepatan dalam peramalan pemulusan eksponensial.

3. Penelitian selanjutnya diharapkan menggunakan metode pengukuran akurasi peramalan yang lain seperti UMBRAE (unscaled mean bounded relative absolute error) sebagai alternatif perbandingan metode pengukuran yang sudah ada sebelumnya.

\section{Daftar Rujukan}

1] Andini, T, D., dan Auristani, P., 2016. Peramalan Jumlah Stok Alat Tulis Kantor di UD ACHMAD JAYA Menggunakan Metode Double Exponential Smoothing. Jurnal Ilmiah Teknologi dan Informasi ASIA (JITIKA), Vol.10, No.1.

[2] Mahkya, D. A., H. Yasin, dan Mukid, M, A., 2014. Aplikasi Metode Golden Section untuk Optimasi ParameterPadaMetode Exponential Smoothing. Jurnal Goussian, Vol. 3,No.4,pp.605614. 
[3] Bidangan, J., Purnamasari, I., dan Hayati, N, M., 2016. Perbandingan Peramalan Metode Double Exponential Smoothing Satu Parameter Brown dan Meotde Double Exponential Smoothing Dua Parameter Holt. Jurnal Statistika, Vol. 4, No. 1.

[4] Subagyo, Pangestu., 1986. Forecasting Konsep dan Aplikasi. Edisi Kedua. Yogyakarta: BPFE.

[5] Montgomery, D.C., C.L. Jennings, \& M.Kulahci., 2008. Introduction to Time Series Analysis and Forecasting. New Jersey: John Wiley \& Sons.Inc.

[6] Kachru, Upendra., 2007. Production and Operations Management: Text and Cases. First Edition. New Delhi: Exel Books.

[7] Kumar, Anil. S, \& Suresh. N., 2009. Operations Management. New Delhi: New Age International (P) Limited.

[8] Makridakis, S., Wheelwright, S.C., McGee, V.E., Andriyanto, U.S(Penerjemah), \& Basith, A (Penerjemah).,1988. Metodedan Aplikasi Peramalan. Edisi Kedua Jilid 1. Jakarta: Erlangga.

[9] Bazaraa, M.S. \& C.M. Shetty., 1990. Nonlinear Programming: Theory and Algorithms. New York: John Wiley \& Sons.

[10] Saputra, N, D., Aziz, A., dan Harjito, B., 2016. Parameter Optimization of Brown's and Holt's Double Exponential Smoothing Using Golden Section Method for Predicting Indonesian Crude Oil Price (ICP). Proc. Int. Conf. on Information Tech., Computer, and Electrical Engineering (ICITACEE),pp.356-360.

[11] Lewis, C.D., 1982. International and Business Forecasting Methods. London: Butterworths.

[12] Hartono., 2008. Statistik Untuk Penelitian. Edisi Revisi. Yogyakarta: Pustaka Pelajar.

[13] Sugiyono., 2015. Statistika Untuk Penelitian. Bandung: Alfabeta.

[14] Hadi, Sutrisno., 2017. Statistik. Edisi Revisi. Yogyakarta: Pustaka Pelajar.

[15] Walpole, R.E., Myers, R.H., Myers, S.L., \& Ye Keying., 2007. Probability \& Statistics for Engineers \& Scientists. Eighth Edition. New Jersey: Pearson Prentice Hall.

[16] Kementrian Energi dan Sumber Daya Mineral Republik Indonesia, 2017. Harga Minyak Mentah Indonesia [Online] Available at: http://statistik.migas.esdm.go.id/ index.php?r=hargaMinyakMentahIndonesia/index. [Accessed 16 September 2017]

[17] Badan Pusat Statistik Indonesia, 2017.Ekonomi dan Perdagangan [Online] Available at: https://www.bps.go.id/.[Accessed 08 Juni 2017] 